\title{
Early spring phosphorus limitation of primary productivity in a NW Mediterranean coastal zone (Gulf of Lions)
}

\author{
Frédéric Diaz ${ }^{1, *}$, Patrick Raimbault $^{1}$, Benyahia Boudjellal $^{2}$, Nicole Garcia $^{1}$, \\ Thierry Moutin ${ }^{1}$
}

${ }^{1}$ Laboratoire d'Océanographie et de Biogéochimie (UMR-CNRS 6535), Centre d'Océanologie de Marseille, Campus de Luminy, 13288 Marseille cedex 09, France

${ }^{2}$ Institut des Sciences de la Mer et de l'Aménagement du Littoral, Staoueli, Algeria

\begin{abstract}
Evidence of phosphorus limitation of algal C- and N-uptake in a NW Mediterranean coastal area (Gulf of Lions) was obtained from a field survey of inorganic and organic N, P and C and from bioassays carried out during the late winter-early spring 1998. Dissolved inorganic nitrogen $\left(\Sigma \mathrm{DIN}=\mathrm{NO}_{3}+\mathrm{NO}_{2}+\mathrm{NH}_{4}\right.$ ) and phosphorus (DIP) distributions showed a clear DIP depletion in the inorganic fractions available for primary production. While below the $150 \mathrm{~m}$ depth, the mean $\Sigma$ DIN to DIP ratio was close to the typical Mediterranean ratio of 22 , while values found in the upper layer (0 to $150 \mathrm{~m}$ ) were about 3 times higher (68.4:1 on average). In this upper layer, N:P (19.9:1) and C:P (159.7:1) ratios in the particulate organic matter were higher than the Redfield ratio and also indicated $\mathrm{P}$ depletion in this fraction. In the dissolved organic pool, $\mathrm{P}$ depletion was higher than in the particulate organic pool, since the mean C:N:P ratios were 1674:75:1 in the photic layer. Dissolved organic forms of $\mathrm{C}$ and $\mathrm{N}$ represented the bulk (ca 94 and $86 \%$, respectively) of the total organic matter, while ca $31 \%$ of the organic $\mathrm{P}$ was in particulate fraction. The apparent imbalance between $\mathrm{N}$ and $\mathrm{P}$ in the inorganic fraction was partly attributed to an imbalance in the corresponding nutrient utilization by the phytoplanktonic community, and partly due to the influence of the Rhone River.

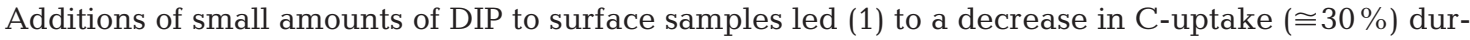
ing the first $24 \mathrm{~h}$ incubation, (2) to a rapid increase in chlorophyll biomass and (3) to stimulate nitrate uptake $(\cong 60 \%)$, suggesting DIP limitation of new production and of algal biomass during the spring 1998 in the Gulf of Lions.
\end{abstract}

KEY WORDS: Nutrients $\cdot$ Phosphorus limitation $\cdot$ Primary productivity $\cdot$ NW Mediterranean

\section{INTRODUCTION}

For a long time, the Mediterranean Sea has been known as an oligotrophic area with lower nutrient concentrations than the adjacent Atlantic Ocean (McGill 1961). If one assumes that N-limited Atlantic water flows through the Gibraltar Strait and that $P$ is recycled faster than $N$, then one could expect $N$ limitation in the photic layer of the Mediterranean Sea. Numerous data, however, show a higher nitrate to phosphate ratio

\footnotetext{
*E-mail: diaz@com.univ-mrs.f
}

in Mediterranean waters than that of 16:1 measured in the Atlantic Ocean (Redfield et al. 1963). The Mediterranean ratio is generally recognized to be higher than 20:1 (McGill 1969), implying a trend of Mediterranean waters to be P-depleted relative to $\mathrm{N}$ (Krom et al. 1991). High inorganic N:P ratios were measured in the eastern basin (Krom et al. 1991) and in the Adriatic Sea (Vukadin \& Stojanski 1976), as well as in the Ionian and Ligurian Seas (McGill 1965). The same dissolved inorganic phosphorus (DIP) depletion was observed in deep waters at several places in the Mediterranean Sea (Miller et al. 1970, Spencer 1983, Coste et al. 1984, Raimbault \& Coste 1990). The review of Berland et al. 
(1980) led to the conclusion that the Mediterranean Sea is different than most other major ocean basins in that $\mathrm{P}$, relative to other macro-nutrients, seems to play an essential role in phytoplankton limitation. P limitation of primary productivity has been demonstrated by nutrient enrichment and bioassay experiments in both the eastern (MacIsaac \& Dugdale 1972) and northwestern Mediterranean basins for the whole year (Devèze 1959, Muñoz \& San Feliu 1972, Jacques et al. 1973a) or for a part of the year (Ballester et al. 1967, Berland et al. 1973, Fiala et al. 1976). In this latter case, $\mathrm{N}$ and iron were then found to play a key role during other times of the year. Hence, Owens et al. (1989) even concluded that $\mathrm{N}$ limitation was more probable than $\mathrm{P}$ limitation in the western Mediterranean. More recently, phytoplankton and heterotrophic bacteria communities were found to be P-limited in the NW basin during summer, which has crucial implications for the dynamics of dissolved organic carbon (DOC) in the photic layer (Zweifel et al. 1993, Thingstad et al. 1998). These latter 2 studies confirmed the theoretical model of Thingstad et al. (1997), in which both phytoplankton and bacteria compete for mineral nutrients associated with a predator control of bacteria biomass allowing DOC to accumulate in summer. Thus, the summer functioning of the microbial food web under P limitation is now well understood, but studies of potential P limitation of phytoplankton or even of heterotrophic bacteria have been scarce for the late winter-early spring in the NW basin. There is no a priori reason to assume ambient nutrient depletion during this period of the year, since strong winter vertical mixing of the water column in this area (Millot 1990) usually allows the supply of sufficient nutrients to the photic layer to initiate the spring bloom a few weeks later (Lefèvre et al. 1997).

However, we herein report a peculiar situation concerning P depletion in the dissolved inorganic pool, as well as in the particulate and dissolved organic matter, in the late winter-early spring 1998 over the Gulf of Lions. These results of $\mathrm{P}$ limitation are supported by the results of bioassay experiments.

\section{MATERIALS AND METHODS}

Sample collection. This study was performed during the MOOGLI 1 Cruise (MOdélisation et Observation du Golfe du LIon) on the RV 'L'Atalante' from March 15 to April 2, 1998 (defined as the early spring period) within the framework of the European Metro-Med and French PNOC (Programme National d'Océanographie Côtière) programs. Hydrological measurements were conducted at 20 stations located within $<200 \mathrm{~m}$ depth and beyond the continental shelf of the Gulf of Lions in the NW Mediterranean Sea (Fig. 1). Samples for nutrient analysis and for total and particulate organic matter measurements were collected at 12 depths between 5 and $400 \mathrm{~m}$, using a rosette system with 121 Niskin $^{\circledR}$ bottles. Profiles of photosynthetically available radiation (PAR) were obtained with an irradiance profiling sensor (QSP-200L, Biospherical ${ }^{\circledR}$ Instruments) fixed on the rosette system. Conductivity, temperature and depth-oxygen measurements were made with a conductivity-temperaturedepth-oxygen profiling system (CTDO Seabird $^{\circledR}$, model 911+). Samples for chlorophyll and productivity measurements were collected only at the surface (5 $\mathrm{m}$ depth) at most of the stations during a second cast of sampling (about $72 \mathrm{~h}$ after the first set). During this second set, nutrients were again determined (at the surface only).

Nutrient analysis and chlorophyll measurements. Samples for ambient nitrite $\left(\mathrm{NO}_{2}^{-}\right)$, nitrate $\left(\mathrm{NO}_{3}^{-}\right)$, ammonium $\left(\mathrm{NH}_{4}^{+}\right)$and DIP concentrations were collected from each depth in polyethylene flasks and immediately analyzed using a Technicon AutoAnalyser $^{\circledR}$ II (precision: $\pm 0.030 \mu \mathrm{M}$ ) according to the working procedures of Tréguer \& Le Corre (1975). Baseline was obtained from a sample of deionized water (Milli- ${ }^{\circledR}$ system). The detection limit (2 SD of the blank) was
Fig. 1. Station locations during the MOOGLI 1 Cruise (March 14 to 30, 1998). ( $\star$ Stations were also sampled for productivity experiments 
$0.050 \mu \mathrm{M}$ for $\mathrm{NO}_{3}{ }^{-}+\mathrm{NO}_{2}{ }^{-}$, and $\mathrm{NH}_{4}{ }^{+}$and 0.015 for DIP. $\mathrm{NH}_{4}{ }^{+}$concentrations were lower than the detection limit of the procedure $(<0.050 \mu \mathrm{M})$ for most of the samples. $\Sigma$ DIN was defined as $\mathrm{NO}_{3}{ }^{-}+\mathrm{NO}_{2}{ }^{-}+\mathrm{NH}_{4}{ }^{+}$, with $\mathrm{NO}_{3}{ }^{-}$content representing 67 to $100 \%$ of $\Sigma$ DIN. Samples for ambient silicate $\left[\mathrm{Si}(\mathrm{OH})_{4}\right]$ concentrations were collected on some occasions and frozen at $-20^{\circ} \mathrm{C}$ until laboratory analyses. At the laboratory, $\mathrm{Si}(\mathrm{OH})_{4}$ contents were manually determined by spectrophotometry (detection limit of $0.050 \mu \mathrm{M}$ ) according to the working procedure of Mullin \& Riley (1955). Samples $(250 \mathrm{ml})$ for chlorophyll a $(\mathrm{chl} \mathrm{a})$ were collected at the surface and immediately filtered onto baked $\left(450^{\circ} \mathrm{C}\right.$ for $24 \mathrm{~h})$ Whatman ${ }^{\circledR}$ glass-fiber filters (GF/F) $(25 \mathrm{~mm}$ in diameter). Chl a concentrations were determined by fluorometry (Turner Designs ${ }^{\circledR}$, model 10.005R) using the methanol extraction procedure (Raimbault et al. 1988).

Particulate organic matter determinations. Samples for particulate organic matter (POM) determinations were collected in acid-cleaned 0.61 polycarbonate (PC) bottles (Nalgene ${ }^{\circledR}$ ) and immediately filtered on baked Whatman ${ }^{\circledR}$ GF/F filters. Filters were then frozen at $-20^{\circ} \mathrm{C}$ until laboratory analysis. Particulate organic carbon (POC), nitrogen (PON) and phosphorus (POP) were simultaneously determined by a wet-oxidation method using sealed vials as outlined by Raimbault et al. (1999a).

Total organic matter determinations. $40 \mathrm{ml}$ of seawater sample for total organic matter (TOM) determinations were directly collected in $50 \mathrm{ml}$ acid-cleaned Pyrex bottles (Duran Schott ${ }^{\circledR}$ ) and fitted with Teflonlined screw caps. Immediately after collection, samples were poisoned with $100 \mu \mathrm{l}$ of mercuric chloride (final concentration $20 \mu \mathrm{g} \mathrm{ml}^{-1}$ ) for preservation until laboratory analysis. Total organic carbon (TOC), total nitrogen (TN) and total phosphorus (TP) were simultaneously determined by persulfate wet-oxidation according to Raimbault et al. (1999b). Concentrations of dissolved organic matter (DOM) were computed by removing the POM fraction and inorganic forms of $\mathrm{N}$ and $P$ from the total matter pool.

Nitrate and carbon uptake experiments. The ${ }^{15} \mathrm{~N}$ tracer method was used to measure nitrate uptake (Dugdale \& Goering 1967). Surface samples were collected in acid-cleaned $0.61 \mathrm{PC}$ bottles (Nalgene ${ }^{\circledR}$ ) and spiked with $\mathrm{Na}^{15} \mathrm{NO}_{3}\left(99.9\right.$ atom\% $\left.{ }^{15} \mathrm{~N}\right)$. Mean ${ }^{15} \mathrm{NO}_{3}{ }^{-}$enrichment was $11.3 \%( \pm 6.8 \%)$ of the corresponding ambient $\mathrm{NO}_{3}{ }^{-}$concentration. Samples were incubated from dawn to dawn under simulated in situ conditions for $24 \mathrm{~h}$ in a deck incubator cooled with sea surface water at $50 \%$ of surface irradiance. Samples were then gently vacuum-filtered (<100 mm Hg) through a baked GF/F and filters were immediately dried at $60^{\circ} \mathrm{C}$. At the laboratory, filters containing
PON were analyzed for ${ }^{15} \mathrm{~N}$ content using a continuous-flow method (Europa Scientific) in which Dumas combustion (Roboprep-CN) is linked in-line to a triple collector mass spectrometer (Tracer mass) via a capillary interface based on the design of Preston \& Owens (1983). Mass-spectrometric signals were used to determine ${ }^{15} \mathrm{~N}$ abundance and total nitrogen mass of samples. Absolute $\mathrm{NO}_{3}^{-}$uptake rates $\left(\mu \mathrm{M} \mathrm{d}{ }^{-1}\right)$ were computed according to Dugdale \& Wilkerson (1986).

C-uptake was determined at the surface using the ${ }^{14} \mathrm{C}$-tracer technique (Steeman-Nielsen 1952) with the experimental protocol of Fitzwater et al. (1982). Acidcleaned $(0.5 \mathrm{~N}, \mathrm{HCl}) 0.321 \mathrm{PC}$ bottles were filled with water sampled with Niskin ${ }^{\circledR}$ bottles and were incubated under the same conditions as in the ${ }^{15} \mathrm{~N}$ experiments. After the bottles were filled, $0.25 \mathrm{ml}$ of a ${ }^{14} \mathrm{C}$ working solution $\left(20 \mu \mathrm{Ci}\right.$ as $\left.\mathrm{NaH}^{14} \mathrm{CO}_{3}\right)$ was added to each bottle. Before incubation, total added ${ }^{14} \mathrm{C}$ activity was assayed on a $0.25 \mathrm{ml}$ aliquot collected in a glass scintillation vial containing $0.25 \mathrm{ml}$ of ethanolamine. At the laboratory, $10 \mathrm{ml}$ of a liquid scintillation cocktail (Ultima Gold ${ }^{\circledR}$ ) and $1 \mathrm{ml}$ of Milli- $\mathrm{Q}^{\circledR}$ water were added to these vials before counting. At each station, additional samples were inoculated with the tracer and immediately filtered to determine blanks. At the end of incubation, samples were filtered onto Whatman ${ }^{\circledR}$ GF/F filters at $<100 \mathrm{~mm} \mathrm{Hg}$. Filters were placed into scintillation vials and wet with $0.25 \mathrm{ml} \mathrm{HCl}(0.5 \mathrm{~N})$. At the laboratory, these vials were dried at $60^{\circ} \mathrm{C}$ for $24 \mathrm{~h}$ and the liquid scintillation cocktail was then added to the dried filters before counting. Counting was performed on a Packard $^{\circledR}$ Tri-carb 2100TR scintillation counter. C-uptake rates $\left(\mu \mathrm{M} \mathrm{d}^{-1}\right)$ were calculated from the equation proposed by Platt \& Sathyendranath (1993). Dissolved inorganic carbon (DIC) concentration was assumed to be $25000 \mathrm{mg} \mathrm{m}^{-3}$ (Robinson \& Williams 1989).

Phosphorus addition experiments. In parallel to productivity samples, additional samples were collected at each station and spiked with DIP. These were then treated under the same conditions as non-DIPenriched samples (controls). DIP additions were fixed to $0.060 \mu \mathrm{M}$, leading to a mean $\Sigma$ DIN:DIP ratio of 17.3 \pm 12 in the bioassays (see Table 2).

\section{RESULTS}

Temperature distribution in the water column showed a typical winter structure, with a large mixed layer down to $50 \mathrm{~m}$ and even to 100-150 $\mathrm{m}$ (Stns I and $\mathrm{R})$ with values ranging between 12.5 and $13.5^{\circ} \mathrm{C}$ in the upper layer (data not shown). Most of the sampled sites presented salinity values ranging between 37.80 and 
(a)

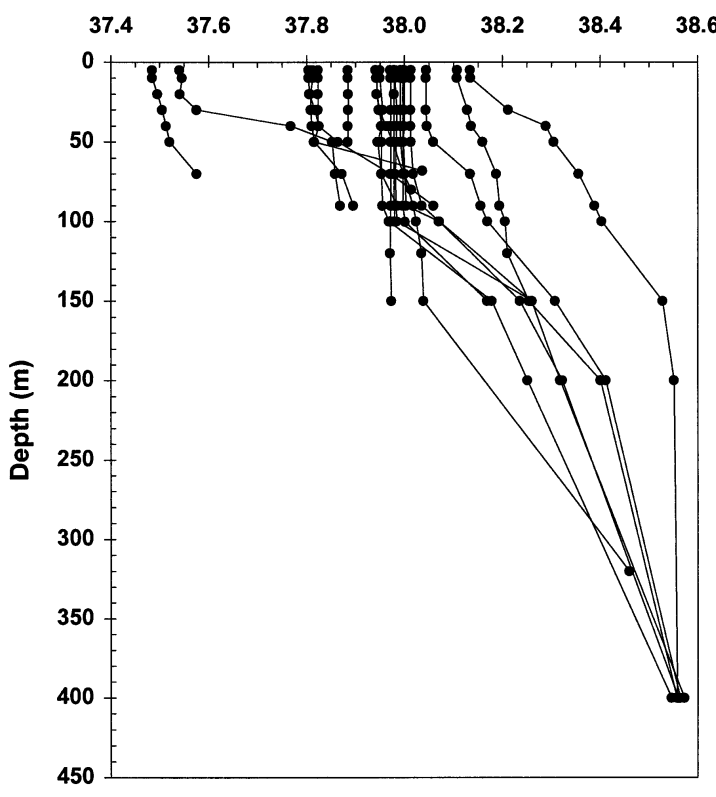

(c)

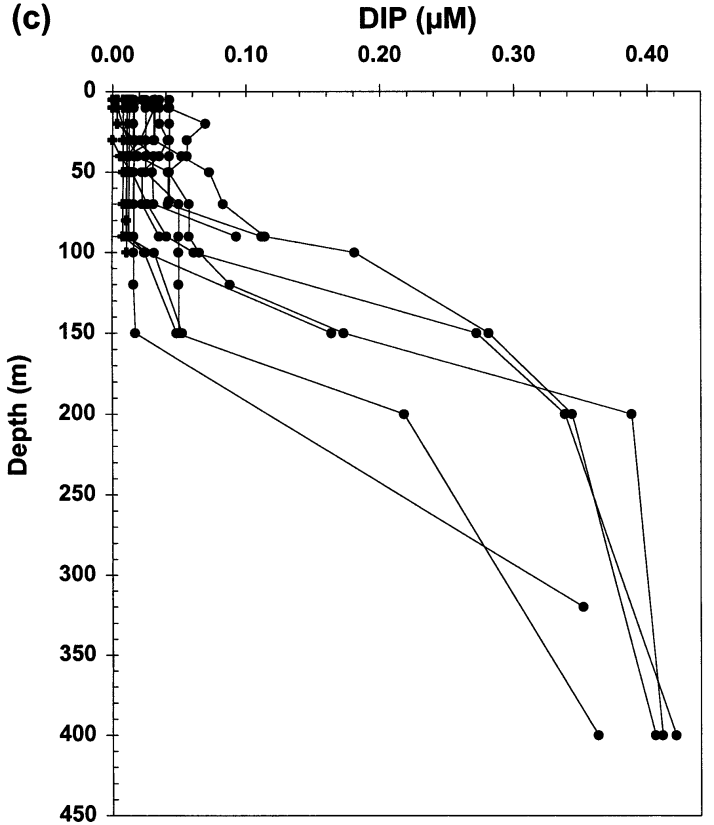

(b)

$\Sigma$ DIN $(\mu \mathrm{M})$

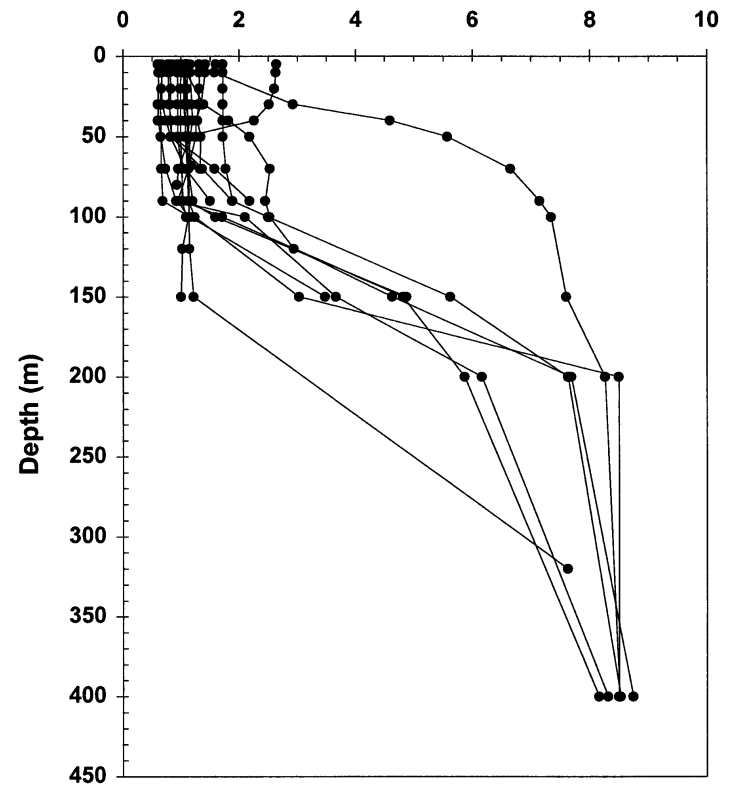

(d)

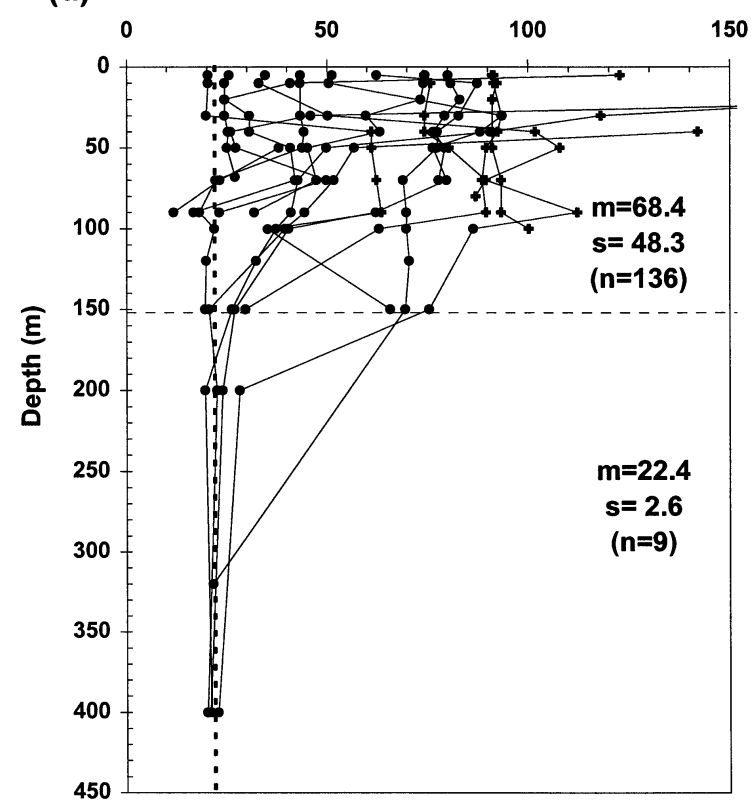

Fig. 2. (a) Salinity, (b) $\Sigma$ DIN $\left(\mathrm{NO}_{3}{ }^{-}+\mathrm{NO}_{2}{ }^{-}+\mathrm{NH}_{4}{ }^{+}\right.$), (c) phosphate (DIP) and (d) $\Sigma$ DIN:DIP molar ratio versus depth at the 20 stations of the MOOGLI 1 Cruise. The vertical dashed line in (d) indicates the value of the $\mathrm{NO}_{3}{ }^{-}$:DIP ratio $(=22)$ reported by McGill (1969) for the Mediterranean area. Mean (m), standard deviation $(\sigma)$ and the number of data $(\mathrm{n}){\mathrm{of} \mathrm{NO}_{3}}^{-}$:DIP ratios were computed for 2 distinct layers (0 to 150 and $>150 \mathrm{~m}$ ). (+) Data representing or based on DIP concentrations below the detection limit

38.05 in the mixed layer, except at 2 stations (Stns K and L) which showed a marked coastal influence (salinity <37.55). Two other offshore stations (Stns E and I) were less mixed and showed high salinity values (>38.10) up to the surface (Fig. 2a). Below the mixed layer, salinity values increased up to 38.55 and were characteristic of Mediterranean Levantine Intermediate Water (LIW).

$\Sigma$ DIN concentrations in the mixed layer (Fig. 2b) were 0.50 to $1.80 \mu \mathrm{M}$ (except at Stn $\mathrm{K}, 2.50 \mu \mathrm{M}$ ) while those of DIP were $<0.040 \mu \mathrm{M}$ (Fig. $2 \mathrm{c}$ ) and often below the detection limit in the photic layer $(0$ to $60 \mathrm{~m})$. Pro- 
files of $\mathrm{Si}(\mathrm{OH})_{4}$ concentrations (data not shown) paralleled those of $\Sigma D I N$ and indicated surface content of 1 to $2 \mu \mathrm{M}$. According to the sampling strategy, nitracline and phosphacline started generally at the same depth. Below the surface mixed layer, DIP and $\Sigma$ DIN concentrations were similar and increased to about $0.401( \pm 0.026, \mathrm{n}=4)$ and $8.52( \pm 0.17, \mathrm{n}=4)$ $\mu \mathrm{M}$, respectively at $400 \mathrm{~m}$. Values (20 to 271) and patterns for the $\Sigma$ DIN:DIP ratio (Fig. 2d) were relatively variable in the upper $150 \mathrm{~m}$ : shallow areas (Stns H and L) had generally a uniform pattern while offshore areas (Stns I and M) showed the highest ratios at the surface. Below $150 \mathrm{~m}$, the $\Sigma$ DIN:DIP ratio always decreased and reached a value of $22.4 \pm 2.6$, which is close to the typical ratio (22 to 21:1) given for the Mediterranean Sea (McGill 1969). On pooling all the data of the $\Sigma$ DIN:DIP ratio from the 0 to $150 \mathrm{~m}$ layer, the arithmetic mean ratio was ca $68 \pm 48$ and was much higher than McGill's (1969) value. Linear regression (model II, Sokal \& Rohlf 1995) of DIP versus $\Sigma$ DIN from the surface to $150 \mathrm{~m}$ gave a calculated slope of 31.34 and an intercept of $0.53 \mu \mathrm{M}$ that was significant $(\mathrm{p}<0.001)$ (Fig. 3). This confirmed (1) the relative DIP depletion in most of the 0 to $150 \mathrm{~m}$ samples, and (2) DIP exhaustion at $\Sigma$ DIN concentrations <ca $0.50 \mu \mathrm{M}$. The PON:POP and POC:POP ratios (Table 1, Fig. 4) seemed to confirm $\mathrm{P}$ depletion in POM in the 0 to $100 \mathrm{~m}$ layer. However, several profiles (for C:P and N:P ratios especially) were slightly lower than the Redfield (1958) ratios (Fig. 4). The mean POC:PON ratio $(8.2 \pm 2.0)$ was higher than the Redfield (1958) standard value of 6.63 (Table 1, Fig. 4). Considering the dissolved organic pool, $\mathrm{C}: \mathrm{P}$ and $\mathrm{N}: \mathrm{P}$ ratios were greater than in the par-

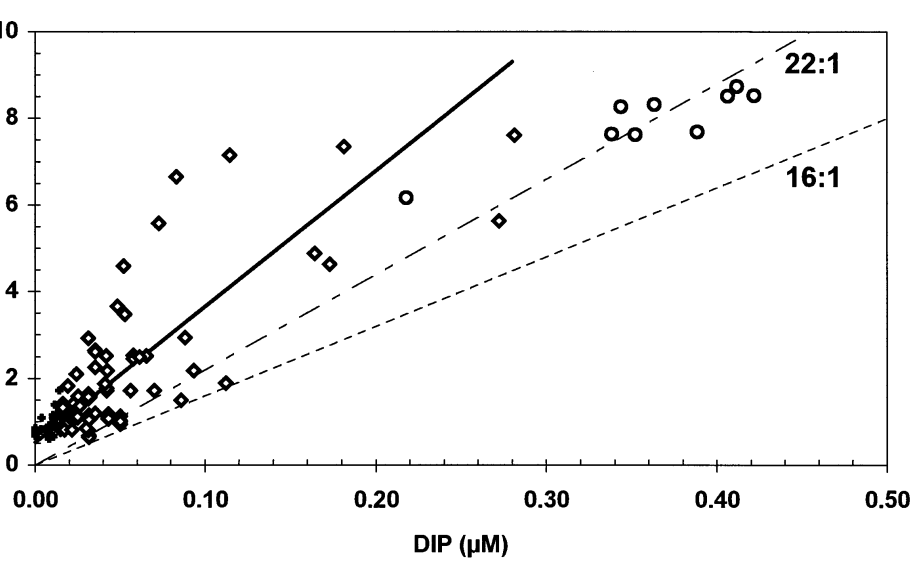

Fig. 3. EDIN versus DIP relationship. ( $)$ From 0 to $150 \mathrm{~m}$ layer; (+) points ayer. Solid line represents the linear regression (model II, Sokal \& Rohlf 995: $\Sigma \mathrm{DIN}=31.34 \mathrm{DIP}+0.53, \mathrm{r}^{2}=0.647, \mathrm{n}=136$ ) of data from the 0 to $150 \mathrm{~m}$ layer. Dashed and dashed-dotted lines indicate the 16:1 (global ocean) and 22:1 (Mediterranean waters) ratios, respectively

ticulate organic pool (Table 1). Particulate organic forms of $\mathrm{C}$ and $\mathrm{N}$ corresponded to only ca 6 and $14 \%$ of the respective total organic forms (Table 1) while ca $31 \%$ of the organic phosphorus pool was in particulate form.

During the second sampling, DIP concentrations were below the detection limit of the methodology, except at 3 stations (Stns H, L and K with values close to the detection limit), while $\Sigma D I N$ ranged between 0.26 and $3.43 \mu \mathrm{M}$ (Table 2). $\Sigma \mathrm{DIN}$ :DIP ratios at these stations were much higher $(>32)$ than the 22:1 Mediterranean ratio. $\mathrm{Chl}$ a concentrations ranged between 0.37 and $3.14 \mathrm{mg} \mathrm{m}^{-3}$. It is worthwhile to note that the highest chl a concentrations were found at Stns $\mathrm{H}, \mathrm{K}$ and L, where DIP was still detectable (Table 2). C- and $\mathrm{NO}_{3}{ }^{-}$uptake rates ranged between 0.51 and $5.78 \mu \mathrm{M}$ $\mathrm{d}^{-1}$ and between 0.019 and $0.62 \mu \mathrm{M} \mathrm{d}^{-1}$, respectively

Table 1. Mean $( \pm \mathrm{SD})$ particulate $(\mathrm{POM})$ and dissolved (DOM) organic matter in terms of carbon (POC and DOC), nitrogen (PON and DON) and phosphorus (POP and DOP) along with corresponding molar ratios obtained from all depths at all stations

\begin{tabular}{|c|c|c|c|c|c|c|}
\hline & POC & PON & POP & $\mathrm{C}: \mathrm{N}$ & C:P & $\mathrm{N}: \mathrm{P}$ \\
\hline $\begin{array}{l}\text { POM }(\boldsymbol{\mu M}) \\
\text { Mean }( \pm \mathrm{SD}) \\
\text { Range } \\
\mathrm{n}\end{array}$ & $\begin{array}{c}5.5( \pm 1.9) \\
1.9-10.4\end{array}$ & $\begin{array}{c}0.69( \pm 0.24) \\
0.22-1.48\end{array}$ & $\begin{array}{c}0.036( \pm 0.014) \\
0.010-0.064\end{array}$ & $\begin{array}{c}8.2( \pm 2.0) \\
3.8-13.9 \\
153\end{array}$ & $\begin{array}{c}159.7( \pm 47.2) \\
88.6-323.9 \\
152\end{array}$ & $\begin{array}{c}19.9( \pm 5.0) \\
10.5-31.5 \\
152\end{array}$ \\
\hline & DOC & DON & DOP & & & \\
\hline $\begin{array}{l}\text { DOM }(\boldsymbol{\mu M}) \\
\text { Mean }( \pm \mathrm{SD}) \\
\text { Range } \\
\mathrm{n}\end{array}$ & $\begin{array}{c}85.9( \pm 13.6) \\
48.9-106.6\end{array}$ & $\begin{array}{c}4.32( \pm 0.42) \\
3.41-5.52\end{array}$ & $\begin{array}{c}0.079( \pm 0.021) \\
0.027-0.147\end{array}$ & $\begin{array}{c}19.8( \pm 3.0) \\
11.5-27.7 \\
134\end{array}$ & $\begin{array}{c}1139.8( \pm 390.8) \\
490.6-3111.1 \\
132\end{array}$ & $\begin{array}{c}56.5( \pm 15.9) \\
31.4-150.2 \\
132\end{array}$ \\
\hline
\end{tabular}



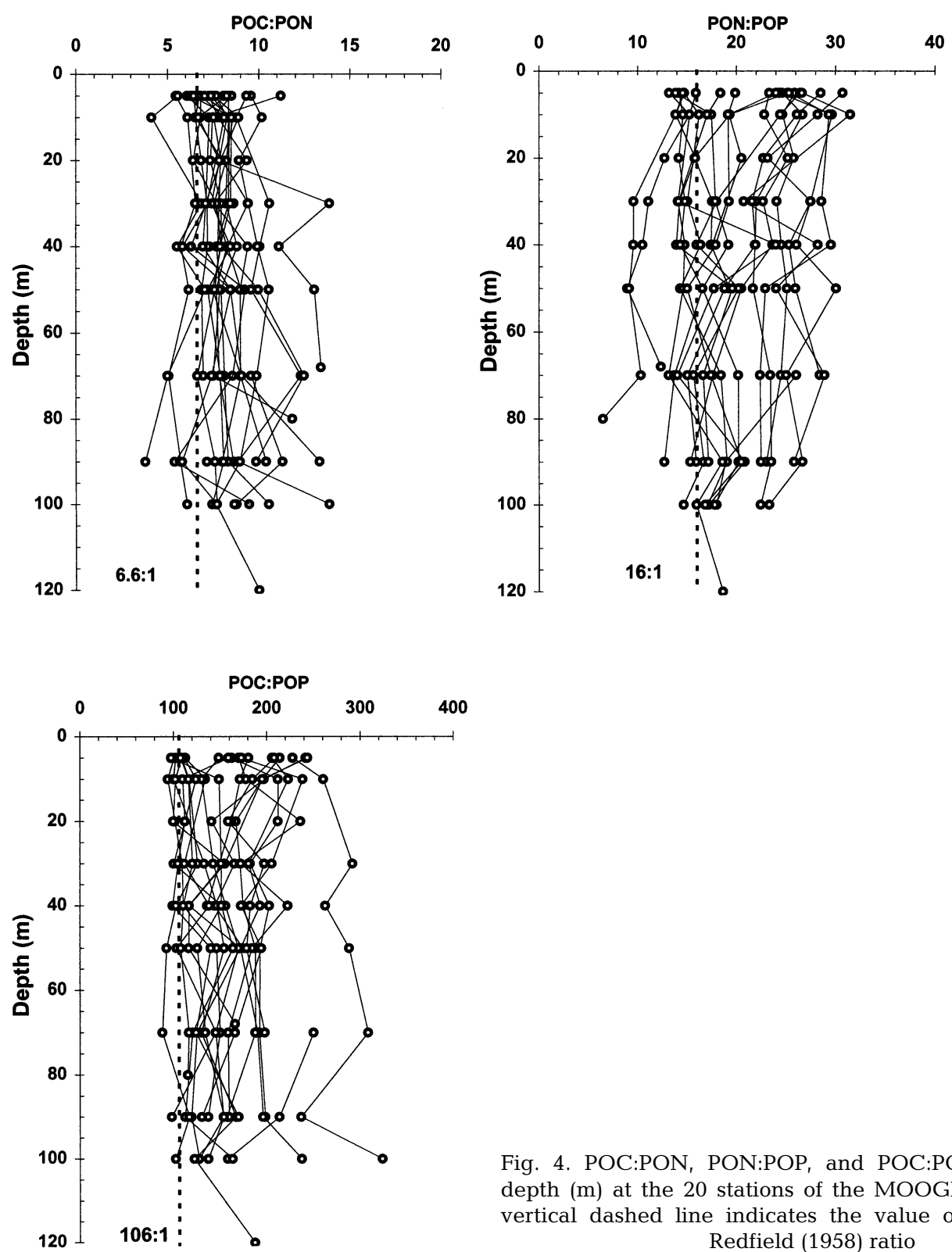

Fig. 4. POC:PON, PON:POP, and POC:POP ratios versus depth $(\mathrm{m})$ at the 20 stations of the MOOGLI 1 Cruise. The vertical dashed line indicates the value of the respective Redfield (1958) ratio

(Table 3). As for chl a concentrations, the highest productivity rates were measured at the stations where DIP concentrations were higher than the detection limit. C-uptake rates measured in the DIP-spiked samples were systematically lower than those obtained from the corresponding control, except at 3 stations, 2 of which (Stns $\mathrm{H}$ and L) were not initially DIPdepleted. Excluding the values of these latter stations, the mean decrease in C-uptake rate was ca $29 \%$ in the DIP-spiked samples. However, this latter decrease is not significant ( $t$-test, $\mathrm{p}>0.15$ ). In contrast, DIP additions resulted in a large enhancement of $\mathrm{NO}_{3}{ }^{-}$uptake at most of the sampled stations. Omitting the 3 stations
(Stns D, N and R) where an enhancement was not observed, $\mathrm{NO}_{3}{ }^{-}$uptake averaged ca $60 \%$ greater in DIP treatments relative to controls. A sample collected at Stn $\mathrm{K}$ was spiked with $0.150 \mu \mathrm{M} \mathrm{P}$ and changes in dissolved nutrient concentrations (LDIN, DIP), $\mathrm{NO}_{3}{ }^{-}$ and C-uptake were then monitored for $3 \mathrm{~d}$ (Fig. 5). At the end of the first daylight incubation $(+12 \mathrm{~h})$, the decrease in $\Sigma$ DIN (Fig. 5a) was low (ca $6 \%$ and ca $14 \%$ in the control and in the DIP-spiked sample, respectively). During this period, the decrease in DIP was significant (ca 40 to $50 \%$ ) in both the control and the DIPspiked sample (Fig. 5b). As for the other stations, the C-uptake rate was lower (by ca $34 \%$ ) in the DIP-spiked 
Table 2. Hydrological data collected at the surface $(5 \mathrm{~m})$ during the second set of sampling ( $72 \mathrm{~h}$ after the first one). $\Sigma$ DIN:DIP* is the $\Sigma$ DIN:DIP ratio in the DIP-spiked productivity samples. DIP additions were $0.060 \mu \mathrm{M}$ except at Stn $\mathrm{K}$ $(0.150 \mu \mathrm{M}) . \mathrm{bdl}=$ below detection limit

\begin{tabular}{|lccccr|}
\hline Stn & $\begin{array}{c}\text { Chl } \\
\left(\mathrm{mg} \mathrm{m}^{-1}\right)\end{array}$ & $\begin{array}{c}\sum \mathrm{DIN} \\
(\mu \mathrm{M})\end{array}$ & $\begin{array}{c}\text { DIP } \\
(\mu \mathrm{M})\end{array}$ & $\begin{array}{c}\sum \mathrm{DIN} \\
\mathrm{DIP}\end{array}$ & $\begin{array}{r}\sum \mathrm{DIN} \text { : } \\
\mathrm{DIP}^{*}\end{array}$ \\
\hline $\mathrm{A}$ & 1.22 & 0.65 & bdl & - & 10.5 \\
$\mathrm{~B}$ & 0.37 & 0.26 & bdl & - & 4.2 \\
$\mathrm{C}$ & 0.73 & 0.38 & bdl & - & 6.1 \\
$\mathrm{D}$ & 0.66 & 0.42 & bdl & - & 6.7 \\
$\mathrm{H}$ & 3.14 & 3.43 & 0.036 & 94.9 & 54.8 \\
$\mathrm{~J}$ & 0.47 & 0.55 & bdl & - & 8.8 \\
$\mathrm{~K}$ & 2.45 & 1.63 & 0.050 & 32.7 & 8.2 \\
$\mathrm{~L}$ & 1.39 & 1.02 & 0.018 & 56.0 & 16.3 \\
$\mathrm{M}$ & 0.99 & 1.82 & bdl & - & 13.1 \\
$\mathrm{~N}$ & 0.69 & 0.71 & bdl & - & 11.3 \\
$\mathrm{O}$ & 0.58 & 1.09 & bdl & - & 17.5 \\
$\mathrm{P}$ & 0.60 & 1.45 & bdl & - & 23.2 \\
$\mathrm{Q}$ & 0.76 & 139 & bdl & - & 22.3 \\
$\mathrm{R}$ & 0.52 & 1.32 & bdl & - & 21.1 \\
$\mathrm{~S}$ & 0.68 & 1.40 & bdl & - & 17.6 \\
$\mathrm{~T}$ & 0.69 & 1.07 & bdl & - & 17.1 \\
& & & & & \\
\hline
\end{tabular}

sample than in the control (Fig. 5c) whereas a large enhancement of $\mathrm{NO}_{3}^{-}$utilization (ca $60 \%$ ) was observed in the DIP-spiked sample (Fig. 5d) relative to the control. During the first dark period, the $\mathrm{NO}_{3}{ }^{-}$ decrease was ca 2.3 times higher in the DIP-spiked sample than in the control (Fig. 5a). Parallel to the $\mathrm{NO}_{3}{ }^{-}$decrease, dark DIP utilization markedly occurred in the DIP-spiked sample while DIP concentration remained stable in the control (Fig. 5b). About 60 and $30 \%$ of the remaining $\mathrm{NO}_{3}^{-}$and DIP, respectively, were consumed during the second period of daylight in the DIP-spiked sample, in contrast to the control where nutrient utilization remained close to zero (Fig. 5a,b). At the end of this second daylight period, $\mathrm{C}$ - and $\mathrm{NO}_{3}{ }^{-}$uptake were much higher, by a factor of ca 2.5 , in the DIP-spiked sample relative to the control (Fig. 5c,d). A decrease in nutrients continued in the DIP-spiked sample during the second night period and $\mathrm{NO}_{3}{ }^{-}$and DIP concentrations were respectively $<0.100$ and $<0.030 \mu \mathrm{M}$ after $48 \mathrm{~h}$ incubation (Fig. 5a,b). At the end of the experiment (60 $\mathrm{h}$ incubation), the DIPspiked sample was $\mathrm{NO}_{3}{ }^{-}$depleted while the control still contained $0.80 \mu \mathrm{M} \mathrm{NO}_{3}{ }^{-}$. At the same time, $\mathrm{C}$ - and $\mathrm{NO}_{3}{ }^{-}$uptake were respectively higher by a factor of ca 1.4 and 2.5 in the DIP-enriched sample than in the control (Fig. 5c,d). In the latter experiment, DIP addition led to a continuous increase (Fig. 5e) in chl a content (from 2.50 to $5.35 \mathrm{mg} \mathrm{m}^{-3}$ ) while the chl a content in the control decreased from the end of the second daylight period (from 3.30 to $2.70 \mathrm{mg} \mathrm{m}^{-3}$ ).

\section{DISCUSSION}

Previous studies performed at the same period as that of the present work, i.e. in late March (Coste et al. 1972, Coste et al. 1977), reported generally higher concentrations of both DIP (3 to 8 times higher) and $\Sigma$ DIN

Table 3. $\mathrm{NO}_{3}{ }^{-}\left(\mathrm{\rho NO}_{3}{ }^{-}\right)$and $\mathrm{C}$-uptake rates measured at the surface $(5 \mathrm{~m})$ during the second set of sampling in the control and in the DIP-spiked sample (+DIP) for $24 \mathrm{~h}$ incubations. PE: photosynthetic efficiency in the control. \% change: difference (in \%) between uptake rates measured in the DIP-spiked sample and the control. Means of the \% change were computed omitting the underlined values. Values from Stn $\mathrm{K}$ are rates obtained from $12 \mathrm{~h}$ incubations. nd: no data

\begin{tabular}{|c|c|c|c|c|c|c|c|}
\hline Stn & $\begin{array}{c}\rho_{\mathrm{NO}} \\
\text { Control }\end{array}$ & $\begin{array}{c}\left(\mu \mathrm{M} \mathrm{d}^{-1}\right) \\
+\mathrm{DIP}\end{array}$ & $\%$ change & $\begin{array}{l}\text { C-uptake } \\
\text { Control }\end{array}$ & $\begin{array}{c}\left(\mu \mathrm{M} \mathrm{d}^{-1}\right) \\
+\mathrm{DIP}\end{array}$ & $\%$ change & $\begin{array}{c}\mathrm{PE}\left(\mu \mathrm{mol} \mathrm{C \mu g} \mathrm{chl} a^{-1} \mathrm{~d}^{-1}\right) \\
\text { Control }\end{array}$ \\
\hline A & 0.12 & 0.19 & 62 & 1.22 & 0.84 & -31 & 1.00 \\
\hline B & 0.02 & 0.04 & 94 & 0.51 & 0.47 & -8 & 1.40 \\
\hline C & 0.09 & 0.11 & 26 & 1.21 & 0.97 & -19 & 1.65 \\
\hline D & 0.05 & 0.05 & -10 & 0.58 & 0.87 & $\underline{49}$ & 0.89 \\
\hline $\mathrm{H}$ & 0.62 & 1.14 & $\overline{84}$ & 5.78 & 8.93 & $\overline{54}$ & 1.84 \\
\hline $\mathrm{J}$ & nd & nd & & 0.88 & 0.74 & -16 & 1.89 \\
\hline K & 0.28 & 0.44 & 57 & 5.07 & 3.59 & -29 & 2.08 \\
\hline $\mathrm{L}$ & 0.10 & 0.17 & 76 & 1.94 & 2.27 & 17 & 1.40 \\
\hline M & 0.11 & 0.14 & 32 & 1.90 & 1.54 & -19 & 1.92 \\
\hline $\mathrm{N}$ & 0.08 & 0.07 & -11 & 0.90 & 0.81 & -10 & 1.31 \\
\hline $\mathrm{O}$ & 0.03 & 0.04 & 24 & 0.73 & 0.43 & -41 & 1.25 \\
\hline $\mathrm{P}$ & 0.06 & 0.09 & 67 & 0.99 & 0.54 & -46 & 1.65 \\
\hline Q & 0.07 & 0.11 & 53 & 1.28 & 1.08 & -16 & 1.69 \\
\hline $\mathrm{R}$ & 0.06 & 0.05 & -15 & 0.83 & 0.42 & -49 & 1.59 \\
\hline $\mathrm{S}$ & 0.03 & 0.05 & 42 & 1.28 & 0.88 & -31 & 1.89 \\
\hline $\mathrm{T}$ & 0.02 & 0.04 & 83 & 1.18 & 0.49 & -59 & 1.72 \\
\hline Mean & & & 58 & & & -29 & 1.57 \\
\hline
\end{tabular}


(a)

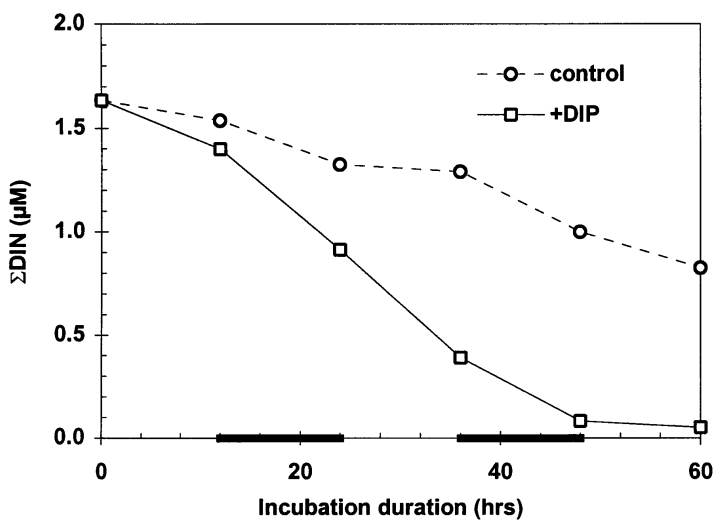

(c)

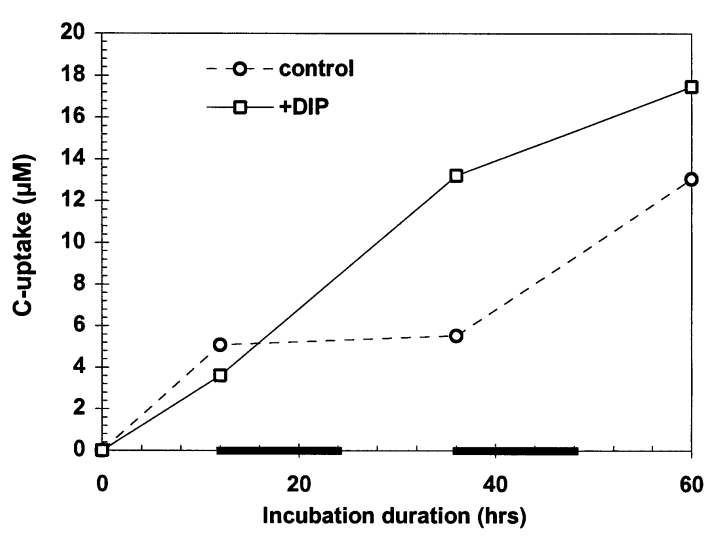

(e)

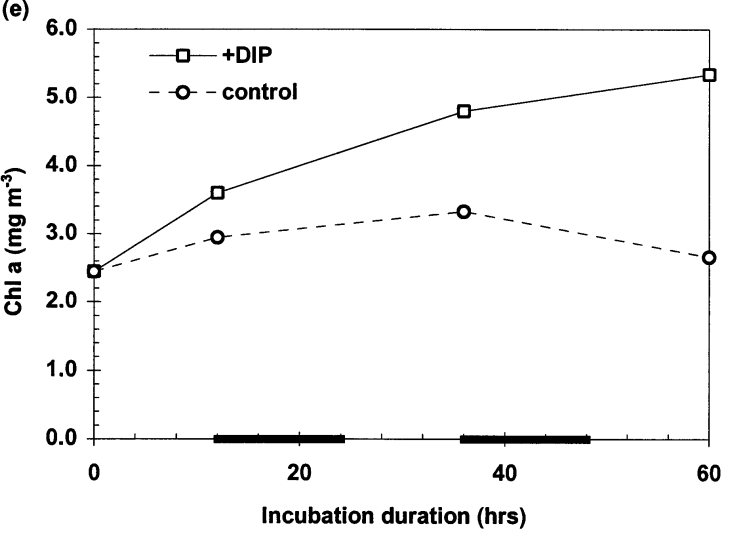

(1 to 6 times higher) in the photic layer. Thus, nutrient stocks in the upper layer appeared to be rather low during our experiment. Earlier studies demonstrated that the nutrient distribution in the Gulf of Lions at the end of winter is directly dependent on previous mixing of the water column (Coste et al. 1972, Lefèvre et al. 1997). This latter process is induced by the strong stress of northwesterly winds (Gascard 1978) and is highly variable over the year, thus resulting in high (b)

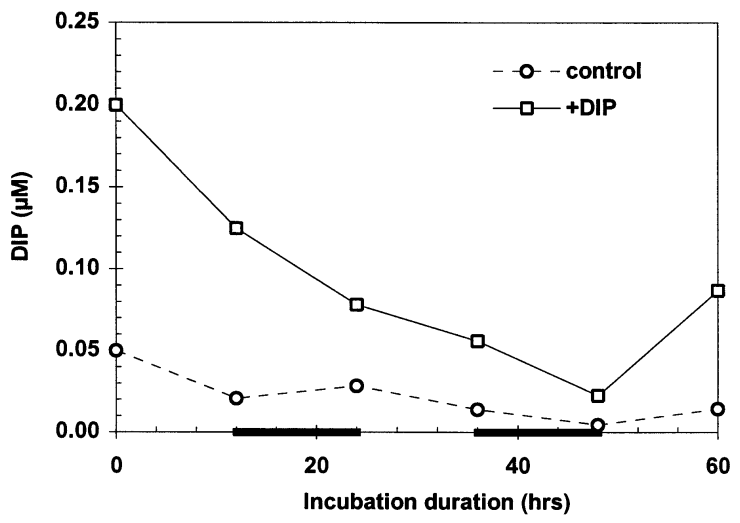

(d)

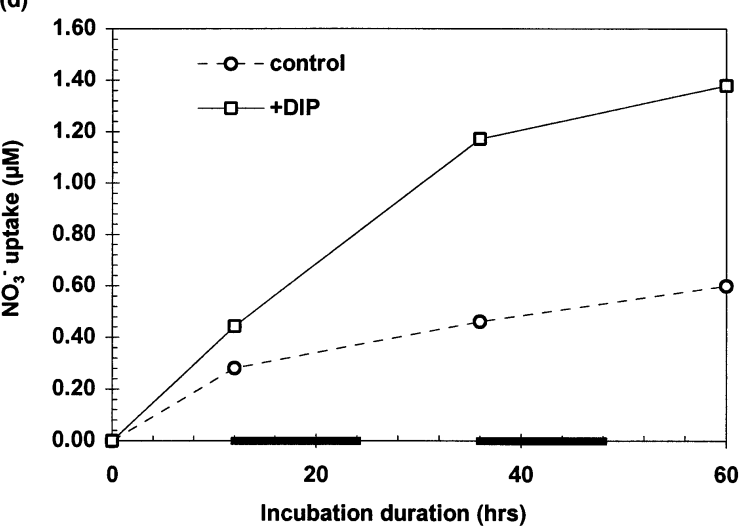

Fig. 5. Data of the time-series phosphorus addition experiment performed at Stn K. (a) $\Sigma$ DIN, (b) DIP, (c) C-uptake rates, (d) $\mathrm{NO}_{3}{ }^{-}$uptake rates, and (e) chl $a$ were followed over $60 \mathrm{~h}$ in a DIP-spiked sample and in a control

variability of nutrient supply to the upper layer. Earlier time-series studies on the evolution of $\mathrm{N}$ and $\mathrm{P}$ stocks in the Gulf of Lions also confirmed the trend of the inter-annual variability of nutrient availability in the early spring (Conan 1996). Therefore, a weak winter mixing of the water column could explain the general low nutrient content of the photic layer during our survey. But this was not likely, since the thickness of the mixed layer (50 to $100 \mathrm{~m}$ ) was similar to that generally 
observed at the end of winter in the area (Coste et al. 1972). Nevertheless, the $\Sigma$ DIN:DIP ratio remained much higher than the reference value of $22: 1$ for Mediterranean areas and concentrations of $\Sigma D I N$ were still significant in the upper layer even when DIP was exhausted (Fig. 3). This observation clearly suggests that $P$ availability was insufficient to meet phytoplankton demand in the whole photic zone. High $\Sigma$ DIN:DIP ratios may be explained by one or several early phytoplankton blooms which could have occurred before the survey. Let us consider a typical deep Mediterranean water with a $\Sigma$ DIN:DIP ratio of $22: 1$ (i.e. DIP $\equiv 0.41 \mu \mathrm{M}$ and $\mathrm{NO}_{3}{ }^{-} \equiv 8.5 \mu \mathrm{M}$ ) reaching the photic layer during winter mixing. Nutrient utilization by phytoplankton with typical N:P requirements of 16:1 (Redfield 1958) would then increase $\Sigma$ DIN:DIP ratios (Fig. 6: see 'theoretical removal') to very high values (>150), with final significant $\mathrm{NO}_{3}{ }^{-}$contents of ca $2 \mu \mathrm{M}$, while DIP concentrations would become $<0.015 \mu \mathrm{M}$. Our data closely fit the curve of 'theoretical' removal (Fig. 6) even if the observed high ratios $(>150)$ cannot be firmly proved experimentally and should be regarded with caution, since conventional methods for measuring DIP do not allow for accurate detection of DIP content below $0.015 \mu \mathrm{M}$. Thus, our model suggests that early phytoplankton blooms were probably the cause of such high $\mathrm{N}: \mathrm{P}$ ratios in the dissolved inorganic fraction of the photic layer. Some other observations further strengthen our hypothesis. Owens et al. (1989) reported low nitrate to phosphate ratios (2.0 to 22.7) in January 1989, i.e. just after the first winter mixing but before the typical bloom period. Jacques et al. (1973b) reported chl a concentrations up to $0.50 \mathrm{mg} \mathrm{m}^{-3}$ in the Gulf of Lions at this period of the year and Morel \& André (1991) concluded from remote-sensed data (CZCS images) that the algae crop does not collapse during winter. On some occasions, we also observed (unpubl. data) high chl a contents (up to $0.80 \mathrm{mg} \mathrm{m}^{-3}$ ) and surface primary production rates (up to $1.6 \mu \mathrm{M} \mathrm{d}^{-1}$ ) during mid-January or February in the Gulf of Lions. Further examination of Fig. 6 showed that most of the $\Sigma$ DIN:DIP ratios for low DIP contents were located below the theoretical curve, indicating an actual gap between the data and the model. In fact, it is likely that another process could result in faster $P$ recycling relative to $\mathrm{N}$ recycling. Some other very high $\Sigma$ DIN:DIP ratios $(>50)$ located at the top of the nitracline immediately below the chlorophyll maximum have been observed in the eastern Mediterranean Basin (Krom et al. 1991) as well as in the western Basin (Raimbault \& Coste 1990). In these cases, the high $\Sigma$ DIN:DIP ratios could be attributed to a phosphacline deeper than the nitracline, suggesting uncompleted $\mathrm{NO}_{3}{ }^{-}$utilization by phytoplankton due to the lack of DIP at the bottom of the photic layer. As demonstrated in the present work,

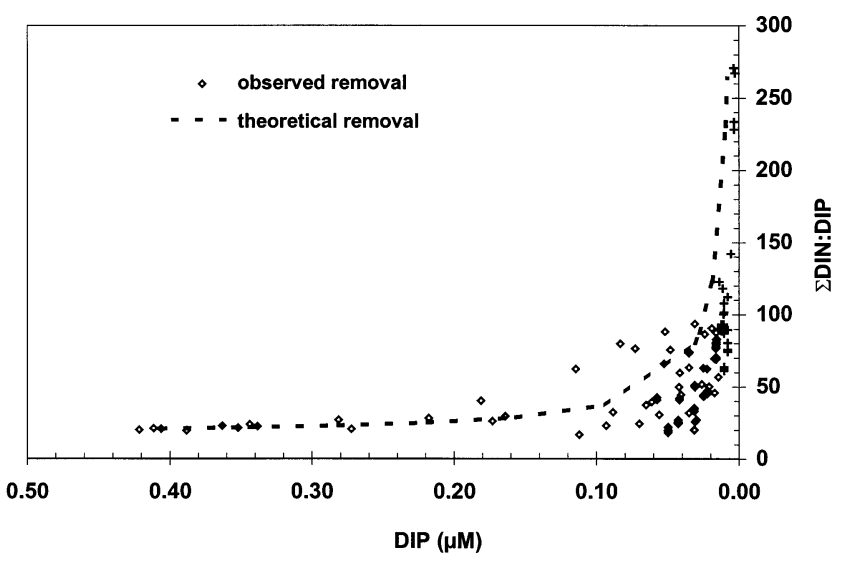

Fig. 6. $\mathrm{NO}_{3}^{-}$:DIP versus DIP relationship. $(\diamond)$ Data; $(+)$ ratios obtained from DIP data below the detection limit. Dashed line represents the theoretical curve of phytoplankton DIP utilization with corresponding $\mathrm{NO}_{3}^{-}$:DIP ratios in upwelled deep Mediterranean water (DIN:DIP $=22$, and DIP $=0.41 \mu \mathrm{M}$ ). The typical Redfield (1958) ratio of N:P requirements (16:1) for phytoplankton was used in the model

such observations may be primarily attributed to the depletion in $\mathrm{P}$ relative to $\mathrm{N}(1: 22)$ in deep Mediterranean waters (Fig. 6). Several suggestions were made to explain the high $\mathrm{N}$ :P ratio of deep Mediterranean waters, including fast $\mathrm{N}$-fixation rates in coastal areas (Béthoux \& Copin-Montegut 1986) and selective phosphate precipitation due to input of iron-containing dust from the Sahara (Krom et al. 1991).

In our study area, the imbalance between $\mathrm{N}$ and $\mathrm{P}$ observed in the surface waters might be also maintained by the Rhone influence. It has been recently emphasized (Moutin et al. 1998) that the N discharge of the Rhone River is mainly in the form of $\mathrm{NO}_{3}{ }^{-}$while a large part (almost half) of $\mathrm{P}$ discharge is in particulate form. According to these findings, the large excess of $\mathrm{N}$ relative to $\mathrm{P}$ (as orthophosphate) in the dissolved inorganic pool led to a mean $\Sigma$ DIN:DIP of ca 70. Considering the organic matter discharges, a mean TN:TP ratio of only ca 15 (Moutin et al. 1998) is measured but the major part of the organic forms do not become available for phytoplankton due to the precipitation and/or rapid sedimentation processes near the Rhone mouth (Martin et al. 1989). Thus, due to the Rhone River inputs, waters in the Gulf of Lions seem to have a $\mathrm{N}$ surplus relative to $\mathrm{P}$ in the inorganic fraction available for primary production. Several other coastal areas heavily influenced by freshwater inputs, such as the northern Baltic (Lignell at al. 1992), Norwegian fjords (Thingstad et al. 1993), the Bay of Biscay (Herbland et al. 1998) and coastal waters of China (Harrison et al. 1990) have been demonstrated to be P- rather than N-limited. In this context, further studies are now required to prove whether, as recently suggested by 
Tyrell (1999) for the global ocean, the external Rhone inputs could control in the long term the balance between $\mathrm{N}$ and $\mathrm{P}$ in the entire Mediterranean Sea.

The existence of nutrient limitation is generally difficult to assert, and low or undetectable chemical measurements of orthophosphate do not necessarily indicate phytoplankton limitation or deficiency (Thingstad et al. 1998). This is because phytoplankton vary greatly in their requirements for $\mathrm{N}$ and $\mathrm{P}$ (Rhee \& Gotham 1980), and some communities can increase their biomass with inorganic N:P ratios that are very different from the Redfield (1958) ratio (Ryther \& Dunstan 1971, Terry et al. 1985). In addition, phytoplankton populations, although under 'systemic' (biomass) limitation (Paasche \& Erga 1988, Cullen 1991) in oligotrophic areas, grow at rates close to their maximum growth rates (Goldman et al. 1979). The growth rate limitation has been termed 'physiological' by Paasche \& Erga (1988). Our results support both types of limitation, particularly during the second set of sampling. According to Thingstad \& Rassoulzadegan (1995), 'systemic' nutrient limitation would be demonstrated by a (temporary or permanent) increase in biomass following the addition of the limiting nutrient to the system. Our time-course experiment, for which an increase in chl a was observed over more than $48 \mathrm{~h}$ in the DIP-spiked sample relative to the control (Fig. 5e), may provide evidence for such a limitation. In addition, stations with measurable DIP contents (Table 2) showed higher chl a concentrations than those with a DIP content below the detection limit. Although our DIP-enrichment experiments cannot unequivocally prove a 'physiological' limitation of the phytoplankton standing stock, one may nevertheless suggest (as outlined in Herbland et al. 1998) a growth rate limitation from the following fact. The mean photosynthetic efficiency (Table 3) was $1.57 \mu \mathrm{mol} \mathrm{C} \mu \mathrm{g} \mathrm{chl} \mathrm{a}^{-1} \mathrm{~d}^{-1}$ and would be equivalent to a growth rate of $0.38 \mathrm{~d}^{-1}$, i.e. a 0.54 doubling $\mathrm{d}^{-1}$ (assuming a phytoplankton carbon-to-chlorophyll ratio of 50, Banse 1977). If the theoretical maximum growth rate is calculated according to Eppley's equation (Eppley 1972), the maximum expected growth rate in these waters would be 1.94 doublings $\mathrm{d}^{-1}$, at an average temperature of $13.10^{\circ} \mathrm{C}$. Though Eppley's equation was obtained from laboratory cultures, this computation would indicate that phytoplankton species in our area may have grown at rates much lower (i.e. ca $28 \%$ ) than their expected maximum rates. Goldman et al. (1979) demonstrated that high growth rates lead to typical C:N:P ratios of 106:16:1, whatever the medium composition in terms of inorganic ratios is, whereas low growth rates imply that C:N:P ratios in the phytoplankton are greatly influenced by the medium composition. Our possibly low growth rates may therefore explain the $\mathrm{P}$ depletion and the high $\mathrm{C}: \mathrm{N}$ ratio observed in the particulate organic matter in some samples (C:N:P ratios of 160:20:1; Table 1, Fig. 4). Our bioassay and time-series experiments provide further evidence for $\mathrm{P}$ limitation of the encountered phytoplankton communities. The non-activation of C-uptake rates observed during the first $24 \mathrm{~h}$ in parallel to the nitrate-uptake enhancement in the DIP-spiked sample is a typical response of autotroph organisms to the addition of a limiting inorganic nutrient. In daylight, $\mathrm{C}$ fixation (i.e. the carbohydrate synthesis) is temporarily reduced or even suppressed to the benefit of nutrient (both $\mathrm{NO}_{3}{ }^{-}$and DIP) uptake (Table 3, Fig. 5) due to competition for photosynthetic reductant between $\mathrm{CO}_{2}$ and N assimilation (Paasche 1971, Falkowski \& Stone 1975, Slawyk \& Collos 1982). Examination of the timecourse results indicates that after $24 \mathrm{~h}$, phytoplankton is back to a balanced growth situation and C-uptake appears to be significantly stimulated by a factor of 1.5 to 2.5. In the DIP-spiked sample, rapid removal ( -40 to $-50 \%$, Fig. $5 \mathrm{~b}$ ) of DIP occurred from the first daylight period, while a high decrease in $\Sigma$ DIN $(-40 \%$, Fig. 5a) was only observed from the first dark period. This pattern of significant $\mathrm{NO}_{3}{ }^{-}$uptake after a delay of $12 \mathrm{~h}$ following DIP addition has been already observed in the oligotrophic area of the tropical Atlantic (Raimbault \& Pujo-Pay 1993). The addition of the limiting DIP probably first induced a reduction in the $\mathrm{NO}_{3}{ }^{-}$consumption because of the redirection of the photosynthetically derived energy to DIP uptake during the first daylight period, as has been previously shown in some laboratory studies (Terry 1982a,b). It is worthwhile to note that the acceleration of nitrate consumption occurred during the dark period following the DIP addition (Fig. 5b). One explanation for that latter feature might be that algae were almost balanced between $\mathrm{N}$ and $\mathrm{P}$ deficiency and that they were likely $P$ replete at the end of the first daylight period; as soon as the algae got some $\mathrm{P}$, they took up $\mathrm{N}$ to balance $\mathrm{P}$ uptake from the first dark period. This is further supported by the observation that some C:P and N:P ratios were close to the Redfield (1958) ratios (Table 1, Fig. 4). However, one should be aware of the potential role of heterotrophic bacteria to compete successfully with algae for dissolved inorganic nutrients (Currie \& Kalff 1984, Hoch \& Kirchman 1995); this feature is particularly obvious in the NW Mediterranean Sea, where P limitation of both heterotrophic bacteria and phytoplankton communities during summer has already been suggested (Thingstad \& Rassoulzadegan 1995, Thingstad et al. 1998). Although we cannot firmly prove from our experiments whether heterotrophic bacteria were P-limited or not during the MOOGLI experiment, the potential role heterotrophic bacteria played in the present work in dark $\mathrm{NO}_{3}{ }^{-}$uptake cannot be ruled out. 
Acknowledgements. This work was supported by the Programme National d'Océanographie Côtière (PNOC-IFREMER-INSU) and by the European program Metro-Med (MAST III). G. Slawyk is acknowledged for constructive comments and suggestions on this manuscript. We also wish to thank D. Tailliez for CTD data, all those aboard the RV 'L'Atalante' for making this study possible, and K. Leblanc for silicate analysis.

\section{LITERATURE CITED}

Ballester A, Arias E, Cruzado A, Blasco D, Camps JM (1967) Estudio hidrografico de la costa catalana, de junio de 1965 a mayo de 1967. Invest Pesq 31:621-662

Banse K (1977) Determining the carbon-to-chlorophyll ratio of natural phytoplankton. Mar Biol 41:199-212

Berland BR, Bonin DJ, Coste B, Maestrini S, Minas HJ (1973) Influence des conditions hivernales sur les productions phyto- and zooplanctoniques en Mediterranée nord-occidentale. III. Caracteristiques des eaux de surface au moyen de cultures d'algues. Mar Biol 23:267-274

Berland BR, Bonin DJ, Maestrini SY (1980) Azote ou phosphore? Considerations sur le 'paradoxe nutritionnel' de la mer Mediterranée. Oceanol Acta 3:135-142

Bethoux JP, Copin-Montegut G (1986) Biological fixation of atmospheric nitrogen in the Mediterranean Sea. Limnol Oceanogr 31:1353-1358

Conan P (1996) Variabilité et bilan de la production primaire en zone côtière (Méditerranée Nord-occidentale; entrée du Golfe du Lion) en relation avec les systèmes biologique, chimique et hydrodynamique (Courant Nord Méditerranéen). PhD thesis, University of Aix-Marseille II

Coste B, Gostan J, Minas HJ (1972) Influences des conditions hivernales sur les productions phyto- et zooplanctoniques en Méditerranée Nord-Occidentale. I. Structures hydrologiques et distribution des sels nutritifs. Mar Biol 16:320-348

Coste B, Jacques G, Minas HJ (1977) Sels nutritifs et production primaire dans le golfe du Lion et ses abords. Ann Inst Océanogr 53(2):189-202

Coste B, Minas HJ, Bonin MC (eds) (1984) Propriétés hydrologiques et chimiques des eaux du bassin occidental de la Méditerranée. Publ Cent Natl Explor Oceans Result Campagnes Mer 26

Cullen JJ (1991) Hypothesis to explain high-nutrient conditions in the open sea. Limnol Oceanogr 36:1353-1358

Currie DJ, Kalff J (1984) Can bacteria out-compete phytoplankton for phosphorus? A chemostat test. Microb Ecol 10:205-216

Devèze L (1959) Cycle biologique des eaux et écologie des populations planctoniques. Rec Trav Stn Mar Endoume Marseille. Hors Ser Suppl 25:1-220

Dugdale RC, Goering JJ (1967) Uptake of new and regenerated forms of nitrogen in primary production. Limnol Oceanogr 12:199-206

Dugdale RC, Wilkerson F (1986) The use of ${ }^{15} \mathrm{~N}$ to measure nitrogen uptake in eutrophic oceans: experimental considerations. Limnol Oceanogr 31:673-689

Eppley RW (1972) Temperature and phytoplankton growth in the sea. Fish Bull US 70:1063-1085

Falkowski PG, Stone DP (1975) Nitrate source in marine phytoplankton: energy sources and the interaction with carbon fixation. Mar Biol 32:77-84

Fiala M, Cahet G, Jacques G, Neveux J, Panouse M (1976) Fertilisation de communautés phytoplanctoniques. I. Cas d'un milieu oligotrophe: Méditerranée nord-occidentale. J Exp Mar Biol Ecol 24:151-163
Fitzwater SE, Knauer GA, Martin JH (1982) Metal contamination and its effect on primary production measurements. Limnol Oceanogr 24:544-551

Gascard JC (1978) Mediterranean deep water formation, baroclinic instability and oceanic eddies. Oceanol Acta 1: 315-330

Goldman JC, MacCarthy JJ, Peavey DG (1979) Growth rate influence on the chemical composition of phytoplankton in oceanic waters. Nature 279:210-215

Harrison PJ, Hu MH, Yang YP, Lu X (1990) Phosphate limitation in estuarine and coastal waters of China. J Exp Mar Biol Ecol 140:79-87

Herbland A, Delmas D, Laborde P, Sautour B, Artigas F (1998) Phytoplankton spring bloom of the Gironde plume waters in the Bay of Biscay: early phosphorus limitation and foodweb consequences. Oceanol Acta 21(2):279-291

Hoch MP, Kirchman DL (1995) Seasonal and inter-annual variability in bacterial production and biomass in a temperate estuary. Mar Ecol Prog Ser 98:283-295

Jacques G, Cahet G, Fiala M, Panouse M (1973a) Enrichissements de communautes phytoplanctoniques neritiques de Méditerranée nord-occidentale. J Exp Mar Biol Ecol 11: 287-295

Jacques G, Minas HJ, Minas M, Nival P (1973b) Influences des conditions hivernales sur les productions phyto- et zooplanctoniques en Méditerranée Nord-Occidentale. II. Biomasse et production phytoplanctonique. Mar Biol 23: 251-265

Krom MD, Kress N, Benner S (1991) Phosphorus limitation of primary productivity in the eastern Mediterranean Sea. Limnol Oceanogr 36:424-432

Lefèvre D, Minas HJ, Minas M, Robinson C, Williams PJLeB, Woodward EMS (1997) Review of gross community production, primary production, net community production and dark community respiration in the Gulf of Lions. Deep-Sea Res 44(3-4):801-832

Lignell R, Kaitala S, Kuosa H (1992) Factors controlling phytoand bacterioplankton in late spring on a salinity gradient in the northern Baltic. Mar Ecol Prog Ser 84:121-131

MacIsaac JJ, Dugdale RC (1972) Interactions of light and inorganic nitrogen in controlling nitrogen uptake in the sea. Deep-Sea Res 19:209-232

Martin JM, Elbaz-Poulichet F, Guieu C, Loÿe-Pilot MD, Han G (1989) River vs. atmospheric input of material to the Mediterrranean Sea: an overview. Mar Chem 28:159-182

McGill DA (1961) A preliminary study of the oxygen and phosphate distribution in the Mediterranean Sea. DeepSea Res 8:259-275

McGill DA (1965) The relative supplies of phosphate, nitrate and silicate in the Mediterranean Sea. ICES Mar Sci Symp 18:737-744

McGill DA (1969) A budget for dissolved nutrient salts in the Mediterranean Sea. Cah Océanogr 21:543-554

Miller AR, Tchernia P, Charnock H, McGill DA (1970) Mediterranean Sea atlas. Woods Hole Oceanogr Inst, Woods Hole, MA

Millot C (1990) The Gulf of Lion's hydrodynamics. Cont Shelf Res 10:885-894

Morel A, André JM (1991) Pigment distribution and primary production in the western Mediterranean as derived and modeled from coastal zone color scanner observations. J Geophys Res 96(C7):12685-12698

Moutin T, Raimbault P, Golterman HL, Coste B (1998) The input of nutrients by the Rhone river into the Mediterranean Sea: recent observations and comparisons with earlier data. Hydrobiologia 373-374:237-246

Mullin JB, Riley JP (1955) The spectrophotometric determina- 
tion of silicate-silicon in natural waters with special reference to sea water. Anal Chim Acta 12:162-170

Muñoz F, San Feliu JM (1972) Hidrographia y fitoplancton de las costas de Castellon, de julio de 1968 a junio 1969. Invest Pesq 36:365-392

Owens NPJ, Rees AP, Woodward EMS, Mantoura RFC (1989) Size-fractrionated primary production and nitrogen assimilation in the Northwestern Mediterranean Sea during January 1989. In: Martin JM, Barth H (eds) EROS 2000, Project Workshop. Comm Eur Communities Water Pollut Res Rep, Paris, p 126-134

Paasche E (1971) Effect of ammonia and nitrate on growth, photosynthesis and ribulosediphosphate carboxylase content of Dunalliela Tertiolecta. Physiol Plant 25:493-501

Paasche E, Erga SR (1988) Phosphorus and nitrogen limitation of phytoplankton in the inner Oslofjord (Norway). Sarsia 73:229-243

Platt T, Sathyendranath S (1993) Fundamental issues in measurement of primary production. ICES Mar Sci Symp 197: $3-8$

Preston T, Owens NPJ (1983) Interfacing an automatic elemental analyzer with an isotope ratio mass spectrometer: the potential for fully automated total nitrogen and 15nitrogen analysis. Analyst 108:971-977

Raimbault P, Coste B (1990) Very high values of nitrate:phosphate ratio $(>30)$ in the subsurface layers of the western Mediterranean Sea. Rapp P-V Reun Comm int Mer Med 32(1):C-18

Raimbault P, Pujo-Pay M (1993) Activation d'absorption de nitrate par l'addition de phosphate dans les eaux de l'Atlantique tropical. C R Acad Sci Paris 361:740-744

Raimbault P, Rodier M, Taupier-Letage I (1988) Size fractionation of phytoplankton in the Ligurian Sea and the Algerian Basin (Mediterranean): size fraction versus total concentrations. Mar Microb Food Webs 3:1-7

Raimbault P, Diaz F, Pouvesle W, Boudjellal B (1999a) A semiautomatic, wet-oxidation method for simultaneous determination of particulate carbon, nitrogen and phosphorus collected on filters. Mar Ecol Prog Ser 180:289-295

Raimbault P, Pouvesle W, Diaz F, Sempéré R (1999b) A simple procedure for simultaneous analysis of total and dissolved organic forms of carbon, nitrogen and phosphorus in seawater using the wet-oxidation technique. Mar Chem 66: 161-169

Redfield AC (1958) The biological control of chemical factors in the environment. Am Sci 46:205

Redfield AC, Ketchum BH, Richards FA (1963) The influence of organisms on the composition of sea-water. In: Hill MN (ed) The sea, Vol 2. Wiley, New York, p 26-77

Rhee GY, Gotham IJ (1980) Optimum N:P ratios and coexistence of planktonic algae. J Phycol 16:486-489
Robinson C, Williams PJLeB (1989) Evidence for physical control of $\mathrm{O}_{2}$ and $\mathrm{TCO}_{2}$ in the outflow of the Rhone estuary. Water Pollut Res Rep 13:387-394

Ryther JH, Dunstan WM (1971) Nitrogen, phosphorus, and nutrients in the coastal environment. Science 171: $1008-1013$

Slawyk G, Collos Y (1982) ${ }^{13} \mathrm{C}$ and ${ }^{15} \mathrm{~N}$ uptake by marine phytoplankton: II. Results from a tropical area (Guinea Dome). ICES Mar Sci Symp 180:209-213

Sokal RR, Rohlf FJ (1995) Biometry. The principles and practice of statistics in biological research. WH Freeman and Company, New York

Spencer D (ed) (1983) GEOSECS, Indian Ocean expedition. Vol 5-6. US Goverment Printing Office, Waschington, DC

Steeman-Nielsen E (1952) The use of radioactive carbon $\left({ }^{14} \mathrm{C}\right)$ for measuring organic production in the sea. J Cons Int Explor Mer 18:117-140

Terry KL (1982a) Nitrate and phosphate uptake interactions in a marine primnesiophyte. J Phycol 18:79-86

Terry KL (1982b) Nitrate uptake and assimilation in Thalassiosira weissflogii and Phaeodactylum tricornutum: interactions with photosynthesis and with the uptake of other ions. Mar Biol 69:21-30

Terry KL, Laws EA, Burns DJ (1985) Growth rate variation in the N:P requirement ratio of phytoplankton. J Phycol 21: 323-329

Thingstad TF, Rassoulzadegan F (1995) Nutrient limitations, microbial food webs, and 'biological C-pumps': suggested interactions in a P-limited Mediterranean. Mar Ecol Prog Ser 117:299-306

Thingstad TF, Skjoldal EF, Bohne RA (1993) Phosphorus cycling and algal-bacterial competition in Sandsfjord, western Norway. Mar Ecol Prog Ser 99:239-259

Thingstad TF, Hagström $\AA$, Rassoulzadegan F (1997) Accumulation of degradable DOC in surface waters: caused by a 'malfunctioning' microbial loop? Limnol Oceanogr 42: 389-404

Thingstad TF, Zweifel U, Rassoulzadegan F (1998) P limitation of heterotrophic bacteria and phytoplankton in the northwest Mediterranean. Limnol Oceanogr 43(1):88-94

Treguer P, Le Corre P (1975) Manuel d'analyse des sels nutritifs dans l'eau de mer. Laboratoire d'Océanographie Chimique. Université de Bretagne Occidentale, Brest

Tyrrell T (1999) The relative influences of nitrogen and phosphorus on oceanic primary production. Nature 400:525-531

Vukadin I, Stojanoski L (1976) C:N:Si:P ratio in the waters of the middle and south Adriatic. ICES Mar Sci Symp 23(7): $41-43$

Zweifel UL, Norrman B, Hagström Å (1993) Consumption of dissolved organic carbon by marine bacteria and demand for inorganic nutrients. Mar Ecol Prog Ser 101:23-32

Submitted: January 31, 2000; Accepted: July 6, 2000

Proofs received from author(s): January 15, 2001 